\title{
Morphological Studies on the C Cells of the Thyroid of Certain Rodents
}

\author{
Bogusław SAWICKI \& Mieczysław KUCZYŃSKI
}

\begin{abstract}
Sawicki B. \& Kuczyński M., 1977: Morphological studies on the C cells of the thyroid of certain rodents. Acta theriol., 22, 17: 251-262 [With 1 Table, 1 Fig. \& Plates XVI-XVII].

Examination was made of calcitonin-producing $(C)$ cells in the thyroids of 97 rodents belonging to species of two families: Muridae and Microtidae. The thyroid was fixed in Bouin's, GPA and BouinHolland's fluid, embedded in paraffin or polyethyleneglycol (Carbovax), sectioned to $6 \mu$ and stained with hematoxyline and eosine and also by the Azan method. C cells in the thyroid were treated with lead hematoxyline, toluidine blue and Giemsa stain and impregnated with silver salts by the Grimelius method. Comparison was made of size, shape, and distribution of $C$ cells and the amount of granular matter in their cytoplasm in different species. It was found that differences in the above feature of $C$ cells are not equally distinct either between families of rodents or between the various species belonging to the same family. The staining methods used for $C$ cells permit of their identification in all the species of rodents examined.
\end{abstract}

[Dept. Histol. Embryol., Medical Academy, 15-089 Białystok, Poland].

\section{INTRODUCTION}

During the last ten years a number of reports have been published on the morphology and histochemistry of calcitonin producing $(C)$ cells of the mammal thyroid. $C$ cells have received relatively detailed examination in the majority of laboratory animals and mammals bred in agricultural practice, and also in man (for detailed references see $\mathrm{S}$ awick i, 1975).

We failed to find any comparative studies of $C$ cells in small rodents in the literature to which we had access, and therefore the purpose of this paper is to make a comparative evaluation of the structure and distribution of $C$ cells in the thyroid gland of small mice and voles, and also to check the usefulness of the recently initiated methods for identification of these cells in relation to these animals.

Reactions revealing the activity of certain enzymes used as $C$ cell markers in these animals are discussed in a separate publication ( $\mathrm{S}$ awi c ki \& K u c z yńs ki 1977). 


\section{MATERIAL AND METHODS}

Examination was made of the $C$ cells of the thyroid gland in 97 rodents of both sexes belonging to 6 species of two families: Microtidae and Muridae (Table 1).

House mice were caught in 1973 in the Białystok area, and forest mice and 10 bank voles were obtained in 1969 from the Mammals Research Institute, Polish Academy of Sciences, at Białowieża (caught in the Białowieża National Park), the remaining 18 voles and all field voles and $P$. subterraneus were obtained from the experimental breeding stock of the Institute. The animals were killed under anaesthesia and the lobes of the thyroid excised and fixed in Bouin's, GPA (Solcia \& Sampietro, 1968) or Bouin-Holland's fluid and embedded in either paraffin or polyethylene glycol (Carbovax) in the manner described by Bagiński (1969). Sections $6 \mu$ thick were stained with hematoxyline and eosine and by the Azan method. $C$ cells were identified by means of the Grimelius silver impregnation method modified by Sawicki \& Bajko (1974), the $\mathrm{HCl}-$ lead hematoxyline (Solcia et al., 1969) and $\mathrm{HCl}$-toluidine blue (Solcia \& Sampietro) after Sawi cki (1971) and HCl-Giemsa stain.

Table 1

Number of rodents examined.

\begin{tabular}{lr}
\hline \multicolumn{1}{c}{ Family and species } & $\mathrm{n}$ \\
\hline $\begin{array}{c}\text { Microtidae } \\
\text { Clethrionomys glareolus (Schreber, 1780) }\end{array}$ & 28 \\
Pitymys subterraneus de Sélys-Longchamps, 1835 & 14 \\
Microtus agrestis Linnaeus, 1761 & 10 \\
Muridae & 15 \\
Rattus norvegicus (Berkenhout, 1769), laboratory, Wistar & 10 \\
Mus musculus Linnaeus, 1758, laboratory & 6 \\
Apodemus flavicollis (Melchior, 1834) & 14 \\
\hline
\end{tabular}

\section{RESULTS}

\section{Identification of $\mathbf{C}$ cells}

It was found that staining by hematoxyline and eosine and the Azan method did not make it possible to identify $C$ cells in the species of rodents examined, whereas the other staining methods clearly revealed $C$ cells. The best results were obtained using the $\mathrm{HCl}$-toluidine blue and $\mathrm{HCl}-G i e m s a$ staining methods, staining $C$ cell cytoplasm metachromatically. The phenomenon of metachromasis appeared after one hour's hydrolysis in $1 \% \mathrm{HCl}$. This hydrolysis did not cause disappearance of the basophilous character of cell nuclei or the capacity for staining of thyreocytes (Fig. 1,2), and consequently it was possible to observe the structure of all the thyroid cells, although with a low degree of contrast of the histological pictures obtained. It is therefore better to 
allow a long period of hydrolysis (10 to 18 hours) in order to distinguish $C$ cells.

$C$ cells in sections taken from thyroid fixed in GPA fluid stained better with toluidine blue than with Giemsa, but in the case of thyroid fixed in Bouin's or Bouin-Holland's fluid, Giemsa gave better results (Fig. 11). Staining with lead hemotoxyline gave similar results, but C cells were less distinctly contrasted with their surrounding (Fig. 5).

Using the modified Grimelius method very distinct cytoplasmatic granular matter in $C$ cells was found in all the rodents examined: $C$ cells became most strongly impregnated after fixing in Bouin's fluid (Fig. 4, 8) and most weakly after fixing in GPA (Fig. 7).

$C$ cells in small rodents were distinctly more weakly impregnated with silver salts than in larger animals and consequently not all of them were completely distinguishable from their surrounding. It was particularly difficult to identify $C$ cells with little cytoplasmatic granules especially in view of the frequent single occurrence of $C$ cells in these animals (Fig. 18).

The best results in identification of $C$ cells in C. glareolus were obtained using the Grimelius method, since it rendered both $C$ cells lying in clusters (Fig. 13) and singly (Fig. 12) very distinct. This method proved slightly less successful in examination of $C$ cells in the thyroid of the rat and laboratory mice, but in these rodents also the majority of $C$ cells contained distinct argentaffin granules in the cytoplasm (Fig. 4, 8): In other species also we always found a certain number of $C$ cells possessing distinct argentaffin granules (Fig. 15, 18).

\section{Morphology}

$C$ cells differ in shape in the rat, being most often slightly elongate, similar in shape to a pear or unshapely pyramid. Some cells were fusiform or oval (Fig. 3,4). Round $C$ cells were very rarely encountered. Some $C$ cells in the intraepithelial position were similar in appearance to thyreocytes (Fig. 2). Some $C$ cells had single short protrusions of cytoplasm. Observations were also made of separate cross-sections of these protrusions (Fig. 5). The dimensions of these cells varied - some were markedly larger than thyreocytes, and other similar in size.

All methods selectively staining the cytoplasm of $C$ cells revealed its distinctly granular structure. Some $C$ cells contained varying amounts of cytoplasmatic granules, which most often accumulated in the pole of the cell turned towards the capillary vessels and were particularly clearly visible when few in number (Fig. 3 ). $C$ cells with a small or medium amount of granules in the cytoplasm occurred most numerously in the 
rat. The nuclei of $C$ cells were most often oval, less often round and usually slightly larger and lighter than the nuclei of thyreocytes, and had one or more often two, large nucleoli.

The $C$ cells of $A$. flavicollis were very similar to those in the rat (Fig. $10,11)$, but the amount of granular matter in the cytoplasms was markedly greater. The $C$ cells of laboratory and wild mice differed distinctly from $C$ cells in the representatives of Muridae mentioned, but hardly differed at all among each other (Fig. 6, 9). $C$ cells of house mice were generally smaller in dimensions than in the rat and were more often elongate in shape. Granular matter was more abundant and more evenly distributed in the cytoplasm. The nuclei of these cells were more often oval or even distinctly elliptic than in the $C$ cells of the rat, and had a more distinct chromatine stroma and usually one large eccentrically situated nucleolus.

$C$ cells in $C$. glareolus are usually rounded in outline, most often oval or egg-shaped, particularly when occurring singly (Fig. 12). They were more rarely of a more or less distinct polygonal shape, when occurring in clusters (Fig. 13). Fusiform shape and also protrusions of cytoplasm were rarely observed in $C$ cells of this rodent. Granular matter was evenly distributed in the cytoplasm. $C$ cells in the thyroid of $P$. subterraneus (Fig. 17, 18) were similar to those in C. glareolus, but were more often elongate in shape (Fig. 17). $C$ cells in the thyroid of $M$. agrestis exhibited the greatest variation in shape of all voles. In addition to elongate $C$ cells, round or multilateral cells were observed (Fig. 15, 16). Some of them had relatively long protrusions. Cytoplasm usually contained a smail amount of granular matter (Fig. 16). The amount of granular matter in the cytoplasm varied in all the $C$ cells of the rodents examined.

\section{Position of $\mathbf{C}$ cells}

In all the animals examined $C$ cells were arranged unevenly in the thyroid, their distribution differing slightly in different individuals of the same species; at the same time certain interspecies differences are found, particularly in respect of their position in relation to the thyroid follicles.

In the rat and $A$. flavicollis $C$ cells were dispersed over almost the whole of the thyroid. They occurred more often in the depth of the gland than on the periphery, where there were parts of the organ totally devoid of them. In laboratory and wild mice $C$ cells clustered inside the thyroid; near its centre these cells occurred in particularly large numbers (Fig. 6). This was usually a region in the immediate vicinity of the internal parathyroid (known as parathyroid IV). In these mice a relatively wide (although varying in extent) external zone of the thyroid was completely 
devoid of $C$ cells. In voles $C$ cells occurred in the interior of the thyroid and in smaller numbers on its periphery, one of the poles of the thyroid being usually completely devoid of $C$ cells. Additional lobes of the thyroid were observed in several of the rodents examined, but no $C$ cells were found in any of them.

In relation to follicles the location of $C$ cells varied but was characteristic of the various species. In the rat, for instance, $C$ cells most often occurred singly in the epifollicular position (Fig. 3, 19-Aa). Groups of $2-3$ cells, also in the epifollicular position, were less often observed (Fig. 4). A small number of $C$ cells occupied an intraepithelial position in the rat, and they sometimes have the impression of being in direct contact with follicular colloid, or even protruding above the internal surface of the follicular epithelium (Fig. 2, 19-Ab). A further few cells in rat occupied an interfollicular position (Fig. 19B). The clusters of $C$ cells arranged near some of the thyroid follicles in the form of a "crown"were characteristic of the rat, although such pictures were only sporadically encountered. Either single $C$ cells, or their complete absence, was observed near neighbouring follicles.

In $A$. flavicollis $C$ cells were distributed in relation to follicles in the same way as in the rat, only the intraepithelial position of $C$ cells being more often encountered in this rodent (Fig. 11).

In both variations of house mice $C$ cells lay singly in the thyroid more often than in the rat and usually occupied an epifollicular, or far less often an interfollicular, position (distinctly less often than in the rat).

In voles clusters of $C$ cells, in usually small cell groups occupying an interfollicular position, were observed more often than in mice (Fig. 13). This tendency to form cell groups was most clearly expressed in the bank vole, and most faintly in the field vole. The intraepithelial position of $C$ cells in the thyroid of voles was, however, found far less often than in mice.

It was difficult to establish with absolute certainty whether the $C$ cells, observed in the interfollicular position lay in the connective tissue on the exterior of the basal membrane of the thyroid follicle (interstitial position) or whether these were groups of these cells in the epifollicular position cut off at a tangent. On this account exact terms were not used, but only the more general definition "interfollicular position ". Individual variation in respect of morphology and distribution of $C$ cells was observed in all the rodents examined, such variation consisting in clusters of varying strength of $C$ cells in the central areas of the thyroid gland, and also in the varying numbers of these cells in the gland and in differences in frequency of occurrence of cells full of cytoplasmatic granular matter and oligogranular cells. 


\section{DISCUSSION}

The phenomenon of "masked metachromasis " cannot be interpreted with complete clarity, but it would seem that it is distinctly connected with the presence of cytoplasmatic granules ( $\mathrm{L}$ i e t z, 1971), containing, as is well known, chiefly calcitonin. The very different degrees of inten-

\section{A. Intrafollicular}
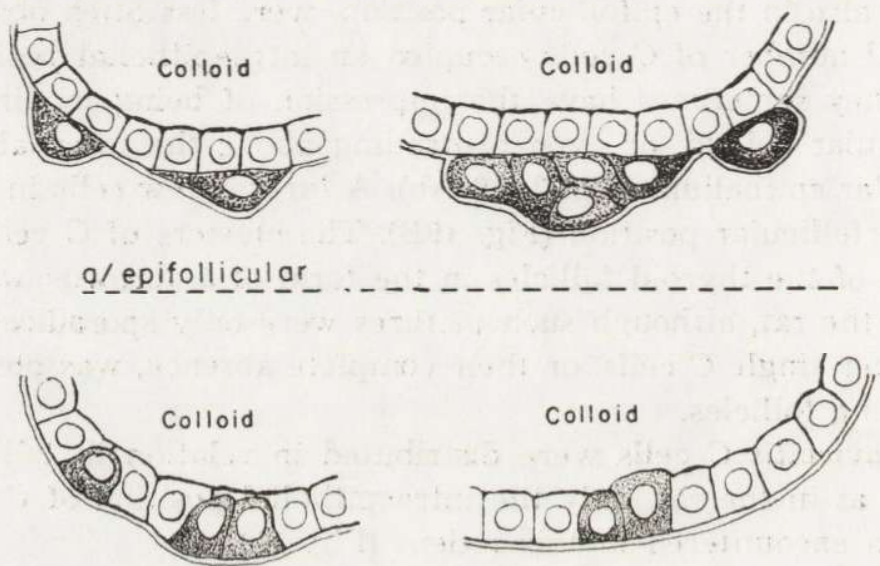

b/ intraepithelial

B Interfollicular = parafollicular

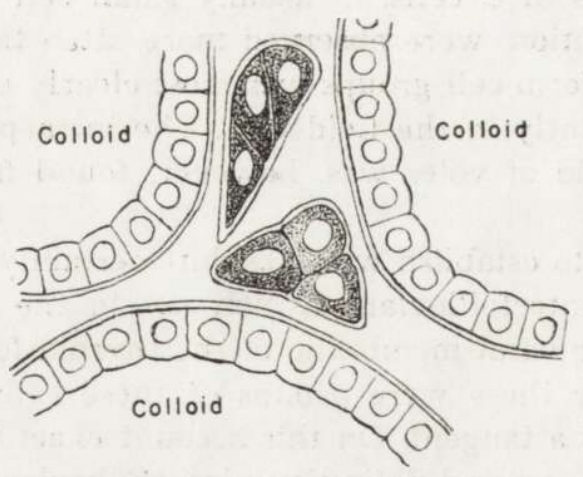

Fig. 19. Diagram showing different positions of thyroid $C$ cells in rodents.

sity of metachromatic staining of $C$ cells which we observed in these rodents is probably evidence of the very variable calcitonin content in different cells.

The relatively large number of $C$ cells possessing very little cytoplasmic 
granular matter observed in these animaly may be the result of intensive metabolism. The studies made by numesous authors (Lietz, 1971; Velický, 1971; Roediger, 1973; Swarup \& Das, 1973; Rouaise et al., 1973/1974; M iętkiewski et al., 1974; S a wicki, 1975; Velický \& Velická, 1975) would appear to show that the polymorphism in a population of $C$ cells is characteristic of all the mainmal species so far examined.

The oligogranular character of the cytoplasm of $C$ cells in small rodents makes their identification difficult and results in varying degrees of accuracy in their differentiation depending on the staining method used. The greatest diagnostic difficulty when employing the Grimelius method is due to the undoubted tendencies for silver salts to be deposited on different membranous structures: when the amounts of granules in the cytoplasm are small this makes it very difficult to identify $C$ cells. The method however merits recommendation, since it permits of relatively exact observation of the morphology of $C$ cells, and particularly of their cytoplasmic protrusions.

The fact that relatively small numbers of $C$ cells with cytoplasmatic protrusions are observed in histological preparations of the thyroid gland does not reflect the true state of affairs. There are in fact far more of these cells but random cross-sections rarely cut along such protrusions.

A question very open to discussion is the way in which the $C$ cells are positioned in relation to thyroid follicles, and this has been discussed in detail in an earlier publication ( $\mathrm{S} \mathrm{awicki}, 1975)$, in which 3 basic possibilities of arrangement of $C$ cells were distinguished: epifollicular, intraepithelial and interstitial. We also observed these same kinds of positions of $C$ cells in all of the rodents examined, although they occurred in differing reciprocal proportions in the various species. Since, however, in many cases it was difficult to state unequivocally whether the observed position of $C$ cells corresponds to the true interstitial or epifollicular position, we decided to discard the term »interstitial position", and in its place introduced the term »interfollicular position" by which we mean both the true interfollicular position of $C$ cells and the pseudo-position resulting from tangential cross-sections of the thyroid follicles.

The term »interepithelial position " should be used in relation to $C$ cells clearly situated in the follicular epithelium, irrespective of whether they have visible contact with colloid. It is important to differentiate between the epifollicular and interepithelial positions of $C$ cells, since when thes cells lie in the interepithelial position they are usually identified (using histological staining methods in common use) as thyreocytes. We trust that the enclosed digram (Fig. 19) will make it possible in future to avoid differences of opinion as to the pasition of $C$ cells in relation to the 
thyroid follicles, and also to avoid the different terminology used by various authors (cf. e.g. Pearse, 1966; Lietz \& Z ippel, 1969 R o edig e r, 1973; Z a b e l, 1974).

\section{REFERENCES}

1. B a g iński S., 1969: Technika mikroskopowa. Państw. Wydawn. Nauk. 1-732 Warszawa.

2. Lietz H. \& Zippel H., 1969: Cytochemische Untersuchungen zur vergleichenden Morphologie der C-Zellen in der Schilddrüse. Z. Zellforsch. mikrosk Anat., 102: $85-98$.

3. Lietz H., 1971: C-cells: source of calcitionin. A morphological review. Curr. Top. Pathol., 55: 109-146.

4. Miętkiewski K., Z Zabel M. \& Linke K., 1974: Comparative studies of the $C$ cells in the thyroid gland of the domestic pig and cat. Folia Histocher. Cytochem., 12: 247-254.

5. Pearse A. G. E., 1966: The cytochemistry of the thyroid $C$ cells and thei relationship to calcitonin. Proc. R. Soc. Lond. (Biol.), 164: 478-487.

6. R o edige r W. E. W., 1973: A comparative study of the normal human neonatal and the canine thyroid $C$ cells. J. Anat., 115: 255-276.

7. Rouais F., Baquey C., Dupuy B. \& Blanquet P., 1973/1974: L'evaluation quantitative du nombre des granulations des cellules parafolliculaires de cellules parafolliculares the thyroides de rat. C. r. Soc. biol. (Paris), 16': $1591-1594$.

8. Sawicki B., 1971: Adaptation of Solcia and Sampietro's method for stabe metachromatic staining of $C$ cells in histologic preparations of the thyroit. Folia morphol. (Warsz.) 30: 401-409.

9. Sawicki B., 1975: Morphology and histochemistry of thyroid gland C cels of young and adult guinea pigs. Acta theriol., 20: 281-296.

10. Sawicki B. \& Bajko K., 1974: Introduction of double impregnation in the method of Grimelius. Folia morphol. (Warsz.) 33: 45-51.

11. Sawicki B. \& Kuczyński M., 1977: Enzymatyczne wyznaczniki komóré kalcytoninotwórczych tarczycy niektórych gryzoni. Folia Histochem. Cytochen. (in print).

12. Solcia E., Capella C. \& Vassallo G., 1969: Lead-hematoxylin as a stain for endocrine cells. Histochemie, 20: 116 -126.

13. Solcia E. \& S a mpetro R., 1968: New methods for staining secretory grinules and 5-hydroxytryptamine in the thyroid C cells. [In: 》Calcitonin: Priceedings of the Symposium on Thyrocalcitonin and C cells", Taylors S. ed]. Heinemann Med. Books: 127-132. London.

14. Swarup K. \& Das V. K., 1973: Studies of calcitonin cells of the Indian grey mongoase Herpestes edwardsi (Geoffroy). Nat. Acad. Sci. India, 42 Am. Ses.: 40 .

15. Velicky J., 1971: Morphology of the parafollicular cells and their relationshp to the other endocrine tissues of the thyroid. II. Observations in the shee), rabbit and cat thyroid. Folia morphol. (Praha), 19: 97-104. 
16. Velický J. \& Velická V., 1975: Light microscopic observations in the thyroid of active bats. Folia morphol. (Praha), 23: 7-13.

17. $\mathrm{Z}$ abel M., 1974: Badania histochemiczne komórek $C$ tarczycy w warunkach prawidłowych i doświadczalnej hiperkalcemii. Msc., Poznań, Akademia Medyczna.

Accepted, November 8, 1976.

Bogusław SAWICKI i Mieczysław KUCZYŃSKI

\section{BADANIA MORFOLOGICZNE KOMOREK KALCYTONINOTWORCZYCH TARCZYCY NIEKTORYCH GRYZONI}

\section{Streszczenie}

Zbadano komórki kalcytoninotwórcze $(C)$ w tarczycy 97 gryzoni-samców i samic, należących do 6 gatunków z rodziny Microtidae i Muridae (Tabela 1). Zwierzęta zabijano w narkozie eterowej. Wypreparowane płaty tarczycy urtwalano w plynach: Bouina, GPA lub Bouina-Hollanda i zatapiano w parafinie lub polietylenglikolu (Carbovax). Skrawki o grubości $6 \mu$ barwiono hematoksyliną i eozyną araz metodą Azan. Komórki $C$ wybarwiano selektywnie za pomoca hematoksyliny ołowiowej, błękitu toluidyny i barwnika Giemsy po wcześniejszej hydrolizie badanych skrawków tarczycy w $\mathrm{HCl}$. Stosowano też impregnację komórek $C$ solami srebra używając metody Grimeliusa.

Porównywano wymiary, kształt, rozmieszczenie komórek $C$ i ilość ziarnistości w ich cytoplazmie u poszczególnych gatunków. Stwierdzono niejednakowo zaznaczone różnice $\mathrm{w}$ wymienionych cechach komórek $C$, widoczne zarówno przy porównywaniu przedstawicieli różnych rodzin jak i gatunków. Zaobserwowano też indywidualne różnice pomiędzy komórkami $C$ niektórych osobników należących do tego samego gatunku.

Stwierdzono ponadto, że cechami wspólnymi komórek $C$ wszystkich zbadanych gryzoni są: ziarnista struktura cytoplazmy, zmienna ilość ziarnistości w cytoplazmie poszczególnych komórek, zmienny kształt komórek i posiadanie przez część komórek wypustek cytoplazmatycznych.

Zastosowane metody swoistego barwienia komórek C (HCl-hematoksylina ołowiowa, $\mathrm{HCl}$-błękit toluidyny, $\mathrm{HCl}$-Giemsa i srebrowa metoda Grimeliusa) pozwalają na ich identyfikację u wszystkich badanych gatunków gryzoni.

\section{Plate XVI}

Fig. 1. Part of the thyroid gland of a white rat fixed in GPA fluid and stained with toluidine blue after 1 hour's hydrolysis in $\mathrm{HCl}$. The cytoplasm of $C$ cells (indicated by arrows) stains more deeply than the cytoplasm of thyreocytes. Not all $C$ cells are distinctly visible against their background. Magn. approx. $750 \times$.

Fig. 2. Part of the thyroid gland of a white rat fixed and stained as in fig. 1 . The $\mathrm{C}$ cell of the thyroid protruding above the surface of the follicular epithelium is marked with an arrow. Magn. approx. $250 \times$. 
F'ig. 3. Part of the thyraid gland of a white rat fixed in GPA fluid and stained with toluidine blue after 12-hour hydrolysis in $\mathrm{HCl}$. Only the cytoplasm of $C$ cells is metachromatically stained. The uneven distribution of granular matter in the cytoplasm of $C$ cells can be clearly seen. Magn. approx. $800 \times$.

Fig. 4. Part of the thyroid gland of a white rat fixed in Bouin's fluid and stained by Grimelius's method. The granular structure of the cytoplasm of $C$ cells can be clearly seen. Magn. approx. $800 \times$.

Fig. 5. Part of the thyroid gland of the white rat fixed in GPA fluid and stained by the lead hematoxyline $\mathrm{HCl}$ method. Cross-sections through the cytoplasmatic pseudopodia of $C$ cells are marked with arrows. Magn. approx. $750 \times$.

Fig. 6. Part of the thyroid gland of a white mouse fixed in GPA fluid and stained by the HCl-toluidine blue method. Magn. approx. $800 \times$.

Fig. 7. Part of the thyroid gland of a white mouse fixed in GPA fluid and stained by Grimelius's method. $C$ cells are far more weakly impregnated with silver salts than after fixing in Bouin's fluid. Magn. approx. $800 \times$.

Fig. 8. Part of the thyroid gland of a white mouse fixed in Bouin's fluid and stained by Grimelius's method. Magn. approx. $800 \times$.

\section{Plate XVII}

Fig. 9. Part of the thyroid gland of a wild house mouse fixed in GPA fluid and stained by the $\mathrm{HCl}$-toluidine blue method. Magn. approx. $800 \times$.

Fig. 10. Part of the thyroid gland of Apodemus flavicollis fixed in GPA fluid and stained by the toluidine blue- $\mathrm{HCl}$ method. Varying numbers and distribution of cytoplasmatic granular matter can be seen in C cells. Magn. approx. $800 \times$.

Fig. 11. Part of the thyroid gland of Apodemus flavicollis fixed in Bouin's fluid and stained by the HCl-Giemsa method. The thyroid follicle can be seen in the epithelium, C cells occupy an intraepithelial position. Magn. approx. $800 \times$.

Fig. 12. Part of the thyroid gland of Clethrionomys glareolus fixed in Bouin's fluid and stained by Grimelius's method. Single C cells clearly visible. Magn. approx. $800 \times$.

Fig. 13. Part of the thyroid of Clethrionomys glareolus fixed and stained as in Fig. 12. A cluster of several $C$ cells can be clearly seen. Magn. approx. $800 \times$.

Fig. 14. Part of the thyroid gland of Clethrionomys glareolus fixed in GPA fluid and stained by the $\mathrm{HCl}$-toluidine blue method. Different. intensity of staining can be seen in the various $C$ cells. Magn. approx. $800 \times$.

Fig. 15. Part of the thyroid gland of Microtus agrestis fixed in Bouin's fluid and stained by Grimelius's method. Magn. approx. $800 \times$.

Fig. 16. Part of the thyroid gland of Microtus agrestis, fixed in GPA fluid and stained by the $\mathrm{HCl}$-toluidine method. The majority of the $\mathrm{C}$ cells contain a very small amount of metachromatically staining granular matter. Magn. approx. $800 \times$.

Fig. 17. Part of the thyroid gland of Pitymys subterraneus fixed in GPA fluid and stained by the $\mathrm{HCl}$-toluidine blue. Magn. approx. $800 \times$.

Fig. 18. Part of the thyroid gland of $P$. subterraneus fixed in Bouin's fluid and stain by Grimelius's method. Magn. approx. $800 \times$. 


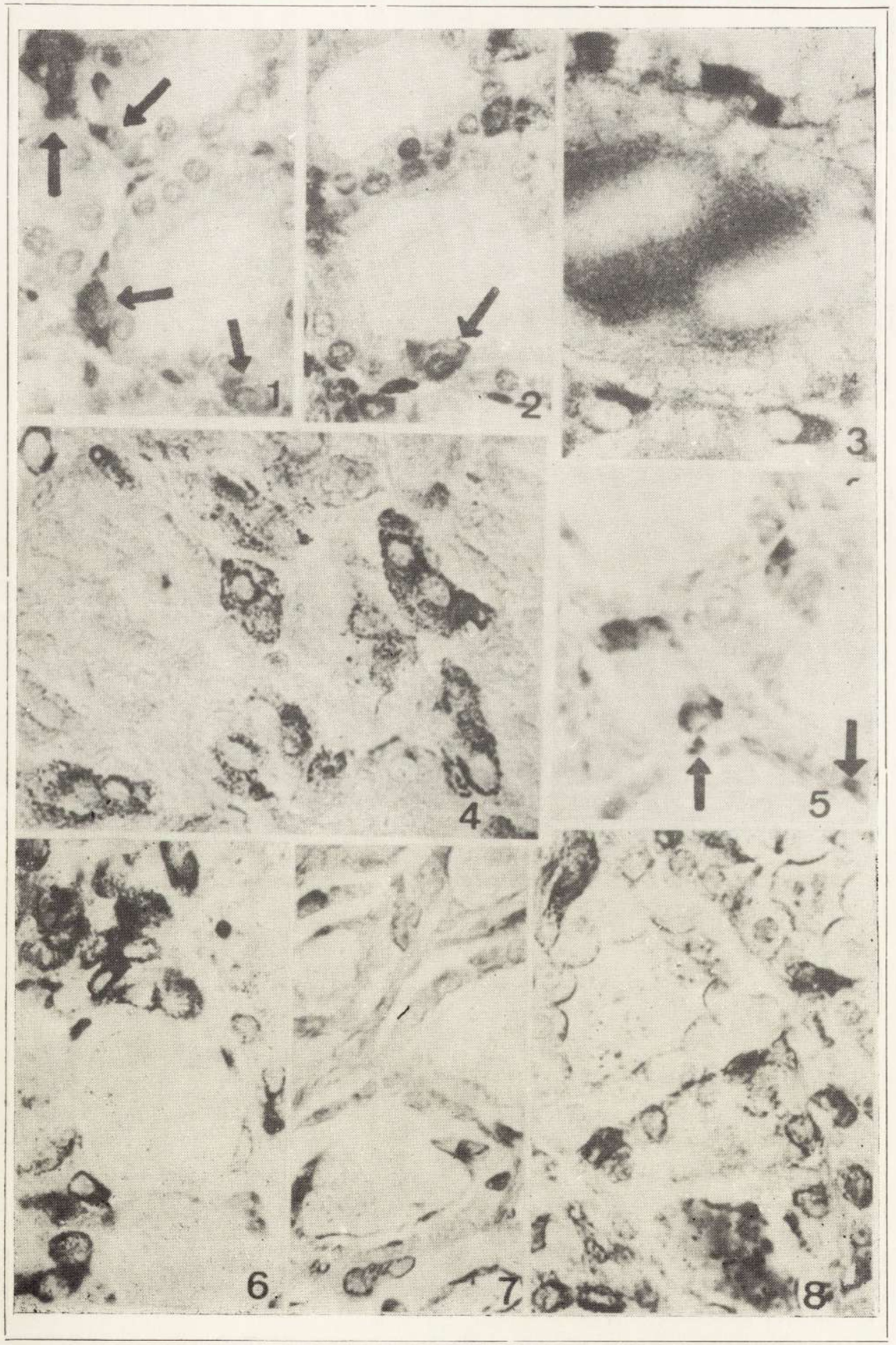

B. Sawicki \& M. Kuczyński 


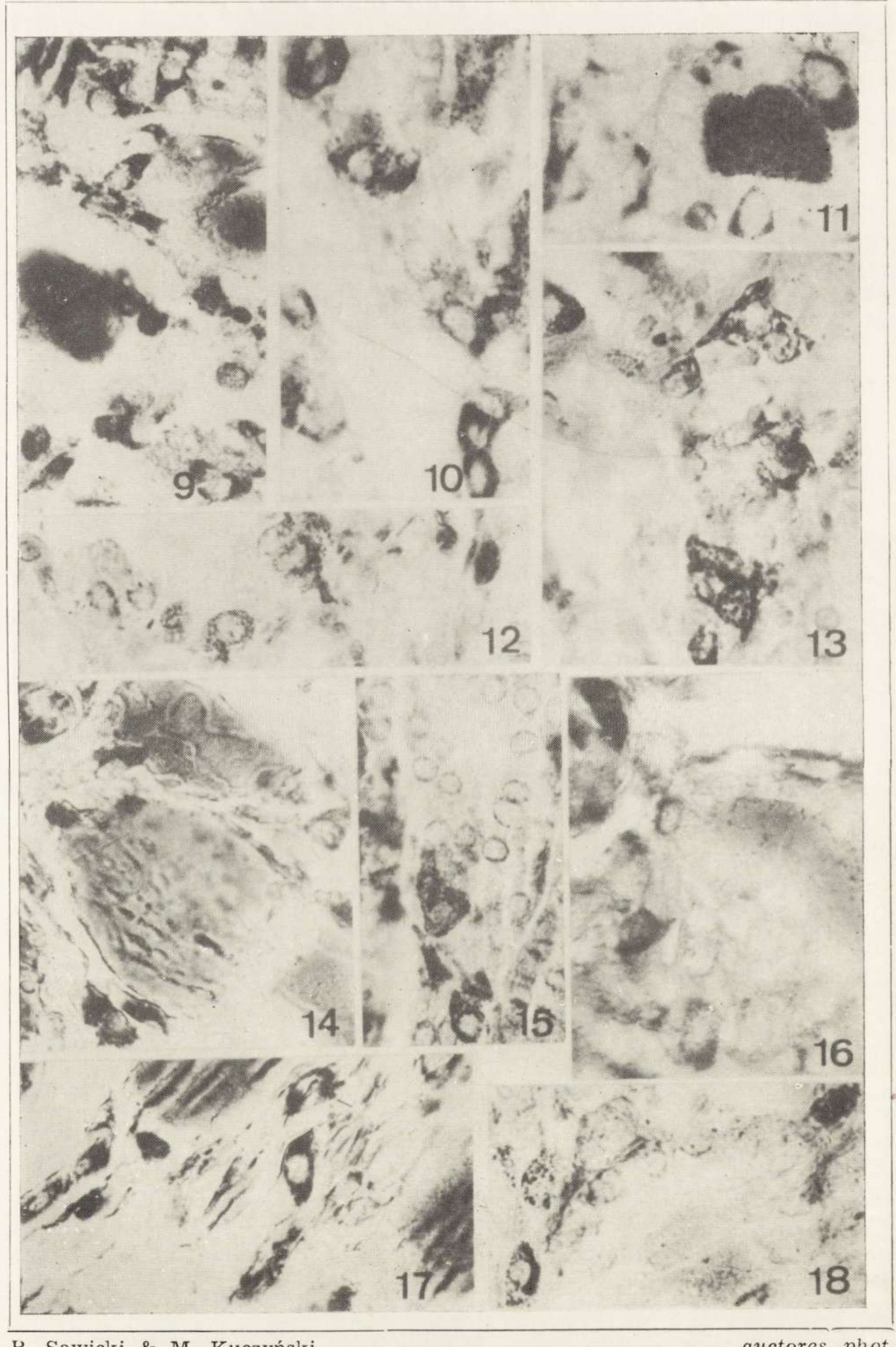

